\title{
OCCURRENCE OF WHITE RUST (Albugo ipomoeae-panduratae) ON Ipomoea acuminata IN THE BRAZILIAN MID-WEST
}

\author{
${ }^{1}$ Pagani, A.P.S.; ${ }^{2}$ Dianese, A.C.; ${ }^{1}$ Inácio, C.A.; ${ }^{1}$ Café-Filho, A.C*.
}

${ }^{1}$ Departamento de Fitopatologia, Universidade de Brasília, Brasília, DF, Brasil; ${ }^{2}$ EMBRAPA-Cerrados, Planaltina, DF, Brasil.

Submitted: January 23, 2011; Returned to authors for corrections: May 30, 2011; Approved: August 30, 2011.

\begin{abstract}
Spontaneous plants of Ipomoea acuminata ("morning glory") exhibiting white rust pustules were found in a field crop area of Planaltina, DF, in the fall season of 2010 and the disease causal agent was identified as Albugo ipomoea-panduratae (Oomycota). No reports of the association between A. ipomoea-panduratae and I. acuminata were known in Brazil previously to 2010. A reference specimen was deposited at the University of Brasilia Mycological Reference Collection.
\end{abstract}

Key words: Ipomoea acuminata, Albugo ipomoea-panduratae, disease aetiology.

Ipomoea acuminata Roem. \& Sch. [sin. Ipomoea indica (Burm.) Merrill, Convolvulaceae], generally known as "morning glory" is a pan-tropical invasive weed of annual and perennial crops. The species is a rapidly spreading vine, reproducing by seed or broken stem fragments. It is an opportunistic coloniser of open, sunny and disturbed habitats, favoured by fertile soils. It is widespread in Brazil (3) and many other countries, where it has been at times introduced as an ornamental species (e.g.: 2). The wheat (Triticum aestivum L.) crop in the Brazilian Mid-West is limited by disease, pests and weeds. Contamination of wheat grain with I. acuminata seeds during the harvest process favours weed dispersion and augmentation of soil seed banks. Inter-specific competition of populations of the genus Ipomoea with other crop species has been studied (6).

During the tillage process for the winter wheat crop at the experimental fields of Embrapa-Cerrados, Planaltina, DF, leaves of spontaneous morning glory plants ("corda-de-viola",
Ipomoea acuminata), were found exhibiting chlorotic spots on the upper leaf surface and white pustules on the corresponding lower leaf areas (Fig. 1 A-C). Infected leaf samples were taken to the Plant Pathology Laboratory at the Universidade de Brasília for micrographic studies. Thin sections (14-20 $\mu \mathrm{m})$ of leaf and fungal tissue were prepared in the cryomicrotome MICRON model HM 505 E (Micron Laborgeräte, Walldorf, Germany). Sections were stained with cotton blue, mounted in semi-permanent slides and sealed with nail polish and examined by light microscopy. Fungal tissue analysis and photographic documentation was done at the Zeiss-Axiophot microscope.

Naturally-occurring symptoms were initially observed as irregular chlorotic patches in the upper foliar surface, which eventually progressed to necrosis. Subsequent to the onset of the chlorotic symptoms in the upper foliar surface, white pustules developed in the lower foliar surface on areas corresponding to the chlorotic areas on the adaxial surface.

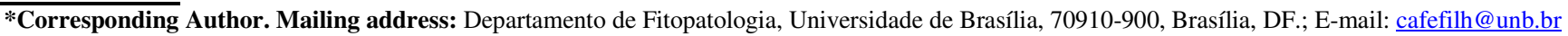


White pustules (0.41-1.8 $\mathrm{mm}$ in diameter), usually disposed in concentric rings, were also found in stems and petioles (Fig. 1 BC). Sporangia were hyaline, initially roundish, and then cylindrical, 10.0-20.0 (15) $\times$ 15.0-25.0 (20) $\mu \mathrm{m}$, with irregular surfaces; Sporangiophores were hyaline, enlarged at the upper end (club-shaped), 7.5-15.0 (10) × 17.5-30.0 (25) $\mu \mathrm{m}$, with smooth surfaces (Fig. 1 D-F). Morphological and morphometric measurements indicated that the specimens collected on $I$. acuminata belonged to the taxon Albugo ipomoeae-panduratae (Schwein) Swingle (Oomycota, Peronosporales, Albuginaceae), a pathogen of the Convolvulaceae $(5,8)$.

Table 1 lists measurements of A. ipomoeae-panduratae, A. candida (Pers.) Roussel and the fungal specimens collected on $I$. acuminata, for comparison purposes. A. candida is widespread and associated to the Brassicaceae in Brazil and elsewhere. A. ipomoeae-panduratae is also pathogenic to Convolvulus spp. and other species of the genus Ipomoea (8), and may be an economically important pathogen of sweet potato (I. batatas) (9).
Reports of A. ipomoeae-panduratae are rare in Brazil. However, a very early report by Viégas \& Teixeira (11) on sweet-potato and $I$. purpurea Lam. is available, from the State of São Paulo (Brazilian South-West). Shortly afterwards, Melo (4) found A. ipomoeaepanduratae in the State of Pernambuco, in the Brazilian NorthEast, presumably infecting sweet-potato (this paper was not recovered). To our knowledge, this is the first recorded association of A. ipomoea-panduratae and I. acuminata in Brazil, and it is the first record of this fungus in the Brazilian Mid-West. Potential consequences of the finding of a rare, but host-specific pathogen, on an invasive species of disturbed habitats, albeit not discussed here, include considerations on biological control. Preliminary reports of this association have been briefly presented at plant pathology meetings in Brazil $(7,10)$. The fungus has also been formerly reported on Ipomoea acuminata in the Dominican Republic (1) and in the US and Oceania (2). Herborized samples were deposited at the University of Brasilia Mycological Reference Collection (CMR-UB), access number UB-21289.
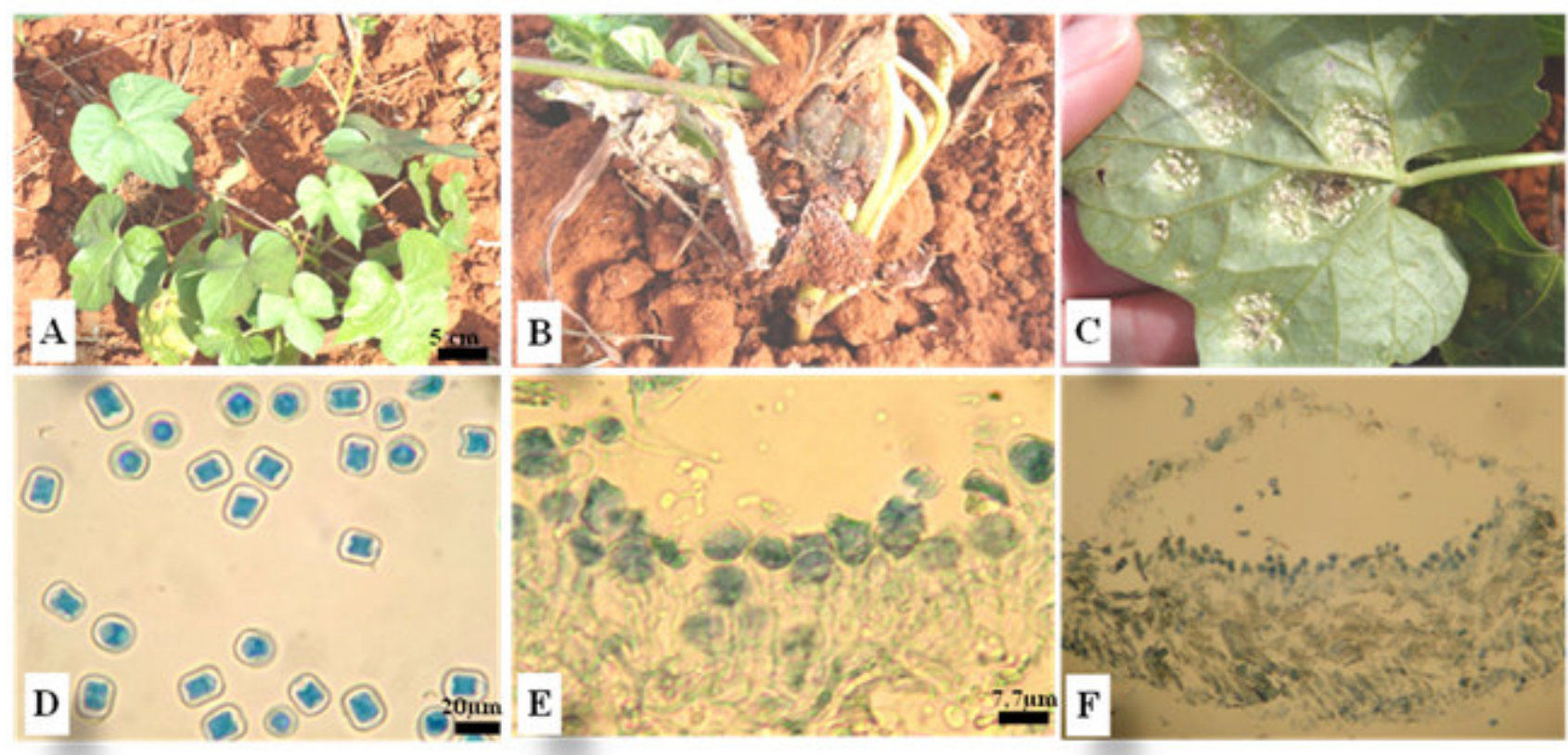

Figure 1. (A) Plants of "corda-de-viola" (morning glory, Ipomoea acuminata). (B) Disease symptoms and signs of the pathogen in stem and petioles. (C) Pustules of Albugo ipomoea panduratae in the lower leaf surface, corresponding to chlorotic patches on the upper surface. (D) Mature cylindrical sporangia and roundish young sporangia. (E) Detail of the club-shaped sporangiophores. (F) Cross section of a leaf pustule. 
Table 1. Morphology and morphometrics of A. candida and A. ipomoea-panduratae

\begin{tabular}{|c|c|c|c|}
\hline & Albugo candida (Pers.) Roussel ${ }^{1}$ & $\begin{array}{l}\text { Albugo ipomoea-panduratae } \\
\text { (Schwein) Swingle }\end{array}$ & $\begin{array}{l}\text { Specimens associated with } I \text {. } \\
\text { acuminata in Brazilian Mid-West } \\
(\text { CMR-UB-21289 })^{2}\end{array}$ \\
\hline Sporangia & $\begin{array}{l}\text { Hyaline, globose to oval, with } \\
\text { thin and uniform walls, arranged } \\
\text { in basipetal chains, } 12-18 \mu \mathrm{m} \text {. }\end{array}$ & $\begin{array}{l}\text { Hyaline, cylindrical to rectangular } \\
\text { with rounded terminal region, } 12-20 \times \\
12-18 \mu \mathrm{m} \text {. Walls display equatorial } \\
\text { thickening. }\end{array}$ & $\begin{array}{l}\text { Hyaline, cylindrical when mature, } 15- \\
25 \times 10-20 \mu \mathrm{m} \text {. Surface walls thick } \\
\text { and irregular. }\end{array}$ \\
\hline ophores & $\begin{array}{l}\text { Hyaline, clavate, } 30-45 \times 15-18 \\
\mu \mathrm{m} \text {, with thick walls, specially } \\
\text { around basis. }\end{array}$ & $\begin{array}{l}\text { Hyaline, club-shaped, } 30-40 \times 12-15 \\
\mu \mathrm{m} \text {, curled at base. }\end{array}$ & $\begin{array}{l}\text { Hyaline, club-shaped, } 17.5-30 \times 7.5- \\
15 \mu \mathrm{m} \text {, smooth, sometimes curled at } \\
\text { base. }\end{array}$ \\
\hline Oospores & $\begin{array}{l}\text { Globose, chocolate-brown, } 30-55 \\
\mu \mathrm{m} \text {, walls thick and usually } \\
\text { ornate. }\end{array}$ & $\begin{array}{l}\text { Spherical, yellowish-brown, } 25-40 \\
\mu \mathrm{m}, \text { papillate or with ridges. }\end{array}$ & Not observed. \\
\hline Pustules (sori) & $\begin{array}{l}\text { White, rarely pale-yellow, of } \\
\text { various sizes and shapes. }\end{array}$ & $\begin{array}{l}\text { White or light yellow, disposed in } \\
\text { concentric rings, with various sizes } \\
\text { and shapes. }\end{array}$ & $\begin{array}{l}\text { White, disposed in concentric rings, } \\
0.41-1.8 \mathrm{~mm} \text { in diameter in leaves, } \\
\text { stems and petioles. }\end{array}$ \\
\hline
\end{tabular}

${ }^{1}$ Saharan \& Verma (1992); ${ }^{2}$ CMR number: University of Brasília Mycological Reference Collection Access Number

\section{ACKNOWLEDGEMENTS}

A.P.S. Pagani and A.C. Café-Filho thank CAPES, Brazilian Posgraduate Agency, and CNPq, Brazilian National Research Council, Proc. 301095/2009-4, for financial support.

\section{REFERENCES}

1. Ciferri, R. (1961). Mycoflora Domingensis Integrata. Quaderno. Laboratorio Crittogamico, Istituto Botanico della Università di Pavia, 19: 539 .

2. Csurhes, S. (2008). Pest plant risk assessment: Blue morning glory Ipomoea indica. Department of Primary Industries and Fisheries Public. Queensland, Australia. 8 pp.

3. Lorenzi, H. (1986). Manual de Identificação e Controle de Plantas Daninhas: Plantio Direto e Convencional, $2^{\text {a }}$. Ed. Nova Odessa SP. 90 p.

4. Melo, J.L. (1947). A ocorrência de Albugo ipomoeae-panduratae
(Schw.) Swingle em Pernambuco. Bol. Agric. Pernambuco, 16: 322-336.

5. Mukerji, K.G.; Critchett. C. (1975). Albugo ipomoeae-panduratae. Descriptions of Plant Pathogenic Fungi and Bacteria. No. 459. Commonwealth Mycological Institute. Kew, Surrey, England.

6. Oliver, L.R.; Frans, R.E.; Talbert, R.E. (1976). Field competition between tall morning glory and soybean. I - Growth analysis. Weed Science, 24: 482-488.

7. Pagani, A.P.S.; Dianese, A.C.; Inácio, C.A.; Café-Filho, A.C. (2010). Ocorrência da ferrugem branca (Albugo sp.) em Ipomoea acuminata no Brasil. Tropical Plant Pathology, 35 (Supplement): 177. (Abstract).

8. Saharan, G.S.; Verma, P.R. (1992). White Rusts. A Review of Economically Important Species. Ottawa. IDRC-CRDI. 65 pp.

9. Sherff, A.F.; MacNab, A.A. (1986). Vegetable Diseases and their Control. 2 nd. Ed. Wiley, New York. 728 pp.

10. Tobias, A.C.; Carneiro, S.G.; Guimarães, G.R.; Marques, P.W.L.; Demo, D.C.; Paz-Lima, M.L. (2010). Ferrugem branca (Albugo spp.) incidente em plantas invasoras no Centro-Oeste. Summa Phytopathologica, 36 (Supplement, CD). (Abstract).

11. Viégas, A.P.; Teixeira, A.R. (1943). Alguns fungos do Brasil (Phycomycetos). Bragantia, 3: 231-269. 